\title{
Enhancing high-rise residential construction through design for manufacture and assembly - a UK case study
}

Colin Banks BSC (Hons), CEng, FICE, MCQI, CQP

Technical Director, Laing O'Rourke, Dartford, UK

(corresponding author: cbanks@laingorourke.com)

Raj Kotecha CEng, MEng, MICE, MIET, MSt, AGCI

Technical Leader, Laing O'Rourke, Dartford, UK

Jason Curtis $\mathrm{MCIOB}$

Project Leader, Laing O'Rourke, Dartford, UK

\author{
Christopher Dee BEng (Hons), CEng, MICE \\ Project Manager, Laing O'Rourke, Dartford, UK \\ Neil Pitt IEng, MICE \\ Head of Precast Design and Engineering, Laing O'Rourke, Dartford, UK \\ Richard Papworth BEng (Hons), CEng, MIStructE \\ Director, Waterman Group, London, UK
}

Buildings forms are often complex and a result of end user needs, local surroundings and aesthetic aspirations. The individuality of buildings has therefore posed challenges with respect to harnessing the desired mass production and standardisation linked with off-site manufacture. However, through design for manufacture and assembly (DfMA), construction can be linked with industrial processes and deliver projects that are safer, cleaner and more efficient. Furthermore, successful DfMA projects minimise disruption within the local environment while delivering not only improved quality, cost and programme certainty, but also a more sustainable form of construction. The Two Fifty One project is a 40-storey mixed-use development in central London, UK, that has successfully embraced the principles of DfMA across all engineering disciplines. As a result, the delivery team has developed effective off-site construction solutions for superstructure, facades, bathrooms and mechanical and electrical services. All have been designed, coordinated and facilitated through advanced digital engineering and building information modelling techniques. Overall, the project has been delivered with reduced programme and cost, while simultaneously improving safety, quality and reliability in a more sustainable way through reduced vehicle movements and greater efficiency in site logistics. This case study describes this exemplary project and the design delivery model.

\section{Introduction}

Over the past 10 years high-rise residential projects, defined to be 20 storeys or more, have been increasing significantly in the UK, most notably in London. It has been reported by the Financial Times (Evans, 2017) that a record 455 new tall buildings are planned or under construction in London as developers push forward the capital's transformation from a lowto high-rise city. The onset of more complex and logistically constrained projects coupled with more demanding stakeholders, the deteriorating quality of traditional build techniques and increasing skills shortages mean that the industry has reached a critical cross-road.

With a call for a step change in productivity and build quality, off-site and modular techniques offer the most realistic solution to this problem. Through design for manufacture and assembly (DfMA) approaches, construction is realising increased productivity in the construction process, tangible quality improvements and the associated reduction in true costs.

DfMA requires a mind-set change from the very beginning in that design and delivery need to be considered in tandem. By applying the principles of DfMA, the industry is transforming traditional construction methodologies into a modern process of componentbased assembly, enabling construction activities such as superstructure build and mechanical/electrical/plumbing (MEP) installation to happen concurrently. Furthermore, DfMA led projects to seek to identify, quantify and eliminate waste or inefficiency in product design, manufacture and assembly.

The following case study describes how the Two Fifty One project, a 40-storey mixed-use development in central London, UK, has successfully embraced DfMA across the design, manufacture, delivery and construction phases to deliver an exemplar for the high-rise residential sector. The $36554 \mathrm{~m}^{2}$ project is a jigsaw of 8436 highly engineered off-site components that form the superstructure, facades, bathrooms and mechanical and electrical services.

\section{Project description}

Project Two Fifty One, shown in Figure 1, is a mixed-use development composed of a two-level basement, 40-storey residential tower and eight-storey commercial block. The residential tower has successfully embraced the principles of DfMA such that $72 \%$ of the frame and facade is manufactured off-site, with bathroom pods and elements of MEP further complementing this. The superstructure extends to $131 \mathrm{~m}$ and is the first-ever built using Laing O'Rourke's patented structural flooring solution, known as E6-H. The combination of prefabricated structural components, facades, bathrooms and mechanical/electrical services has together delivered a shorter construction programme with improved cost certainty, quality, safety and logistics. 


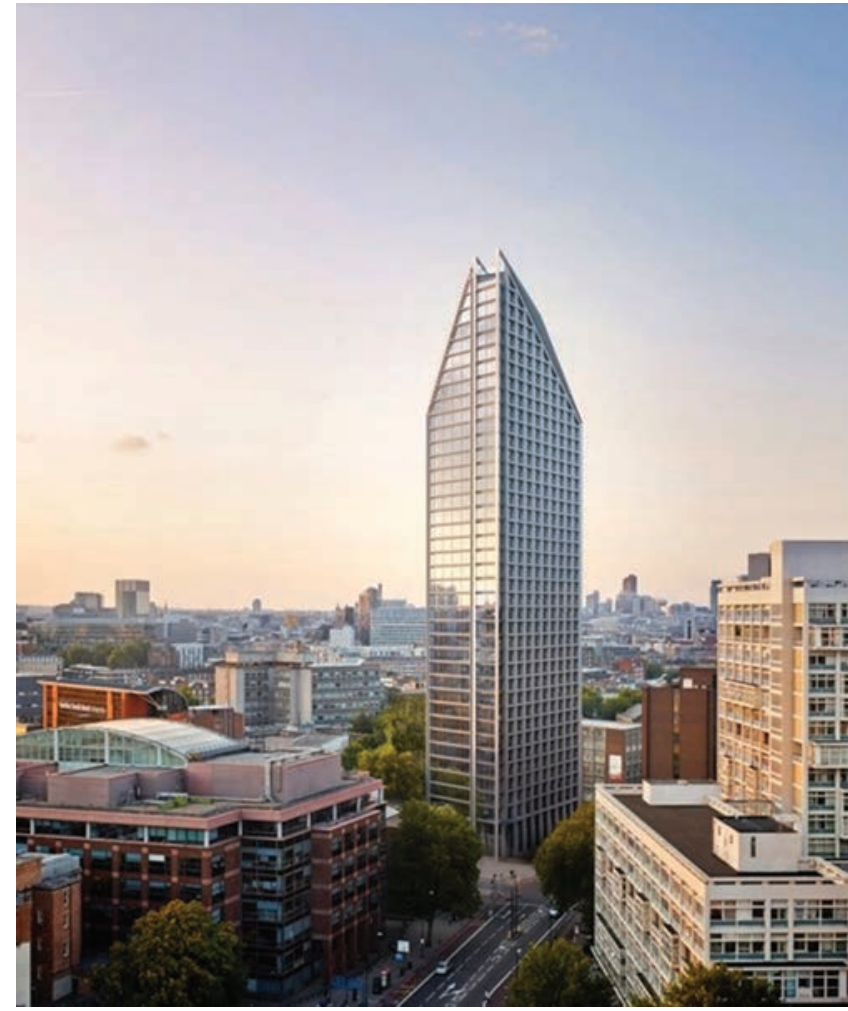

Figure 1. Computer-generated image of Two Fifty One, Elephant and Castle, London - south-west elevation

Laing O'Rourke's approach as principal contractor involves integrated direct delivery and collaboration from in-house companies. Together with the supply chain, the project has been fully designed, coordinated and constructed in the digital environment prior to delivery on-site.

The precast concrete structural components, prefabricated facade panels, bathrooms pods, plant room modules and horizontal and vertical building service modules were all manufactured and where required, is part commissioned, off-site and delivered to the project using a just-in-time approach.

Efficiency and certainty were further enhanced through advanced data exchange and component tracking. For example, the progress of design, through manufacture to logistics and installation was tracked through the digital model, and in order to ensure seamless manufacture, the design of the superstructure was undertaken with the capabilities of the automated factory processes in mind. Overall, the key enablers to the success of the project have been early engagement, an established client relationship, integrated direct delivery approach and optimised in-house manufacturing capabilities.

\section{General case for DfMA}

Building projects such as Two Fifty One are an intricate blend of products. Each of these products has differing costs, customisation and associated build complexities. Therefore, the individuality of buildings poses challenges with respect to harnessing the desired mass production and standardisation linked with off-site manufacture. However, through DfMA, people are able to link construction with industrial processes and deliver projects safely to a higher quality standard and with greater predictability of the final outcome. The DfMA approach redefines the traditional phases of project delivery. This means agreeing and locking down the design phase much earlier to allow the manufacturing, assembly, testing and commissioning phases to be compressed and run in parallel, rather than in one long linear sequence.

Formal DfMA methods began in the late 1970s and systems followed in the 1980s. The early adopters were the same people who first embraced solid modelling techniques - the aeronautical and automotive industries, Boeing, Lockheed Martin, Ford, General Motors and the like. Through the 1990s and 2000s, DfMA techniques became fully embedded and refined within these industries.

However, the construction industry has seriously lagged in this area, categorised by its traditional low investment, low research and development strategies, labour-intensive methodologies, poor health and safety and variable quality. Only in the past 10 years or so has the UK construction industry started to show any serious interest in DfMA approaches. There is now some momentum behind this approach, fuelled by a buoyant UK property market, particularly in London; challenges with high levels of migrant labour and the uncertain post-Brexit implications; and the transformation to highrise buildings, which by definition should provide more repetitive floor-by-floor solutions. The progress within the construction sector in digital engineering (building information modelling), is helping to enable DfMA capability. Certain visionary organisations are building their future strategy around DfMA, with it becoming an integral part of the way they deliver projects for clients.

Key advantages of DfMA include

- speed - significantly reduced programme time on-site through the use of prefabricated elements and modules

- lower cost - by using fewer parts, reducing the number of unique parts and decreasing the amount of on-site labour which is generally more expensive than factory-based labour

- safety improvement - by removing labour-intensive construction activities from site and instead placing the prefabrication activities in a controlled factory environment, together with making the on-site assembly activities easier and cleaner

- higher quality - a highly automated approach should enhance efficiency and quality

- sustainability - less waste in the process overall, greater efficiency in site logistics and a reduction in overall vehicle movements transporting materials to and from site

- reliability - DfMA should improve reliability by lowering the number of parts and reducing the proportion of work carried out in the relatively harsh site environment, thereby decreasing the risk of failure in operation. 


\section{Application of DfMA principles to Two Fifty One}

The Two Fifty One project embraces the latest in modern methods of construction; built with a component-led approach, elements of the structure, facade, MEP systems and fit-out have all been modularised. In total, the project is a kit of 8436 prefabricated components, assembled to deliver the $36554 \mathrm{~m}^{2}$ gross internal area, which provides for 335 apartments, amenity space and commercial offices at levels one and two. Table 1 outlines the product set used in delivering the project and summarises key benefits each component delivers.

The vertical structure is formed using three principal components: precast concrete columns, a twinwall core and solidwall stair and lift shafts. The horizontal structure is then constructed using a combination of solid balcony slabs, lattice slab and the Laing O'Rourke-patented E6-H system. The E6 system is centred on an innovative jointing technology through which a monolithic slab construction can be achieved by a $200 \mathrm{~mm}$ stitch, rather than traditional lap lengths. At Two Fifty One, the E6 joint is able to connect a reinforced concrete edge beam (primary span) with prestressed planks that incorporates full-length headed reinforcement bars within intermittent fully grout-filled cores. In all cases, the headed bars project beyond the limits of the secondary planks and, when installed, interface with an equivalent headed bar provision in the primary plank, forming an in-plane joint through a strut and tie mechanism. This jointing technique is discussed in detail within the design section of this case study.

The carefully chosen component set in use at the project has enabled the construction team to construct a floor every $6 \mathrm{~d}$. However, as part of the smarter construction methodology adopted, this $6 \mathrm{~d}$ cycle also includes $1 \mathrm{~d}$ of prefabricated bathroom pod lifting and half a day window frame lifting. The fact that the team were able to load out the slab with pods and frames was a result of having minimal temporary supports and sufficient strength developed in the joints in $24 \mathrm{~h}$. Figure 2 shows a typical $920 \mathrm{~m}^{2}$ plate at Two Fifty One with the temporary works and bathroom pods (orange boxes) installed.

Overall, the rapid and virtually prop-free construction methodology has enabled a smarter prefabricated MEP and fit-out solution. The

Table 1. Schedule of components used to the deliver the Two Fifty One project

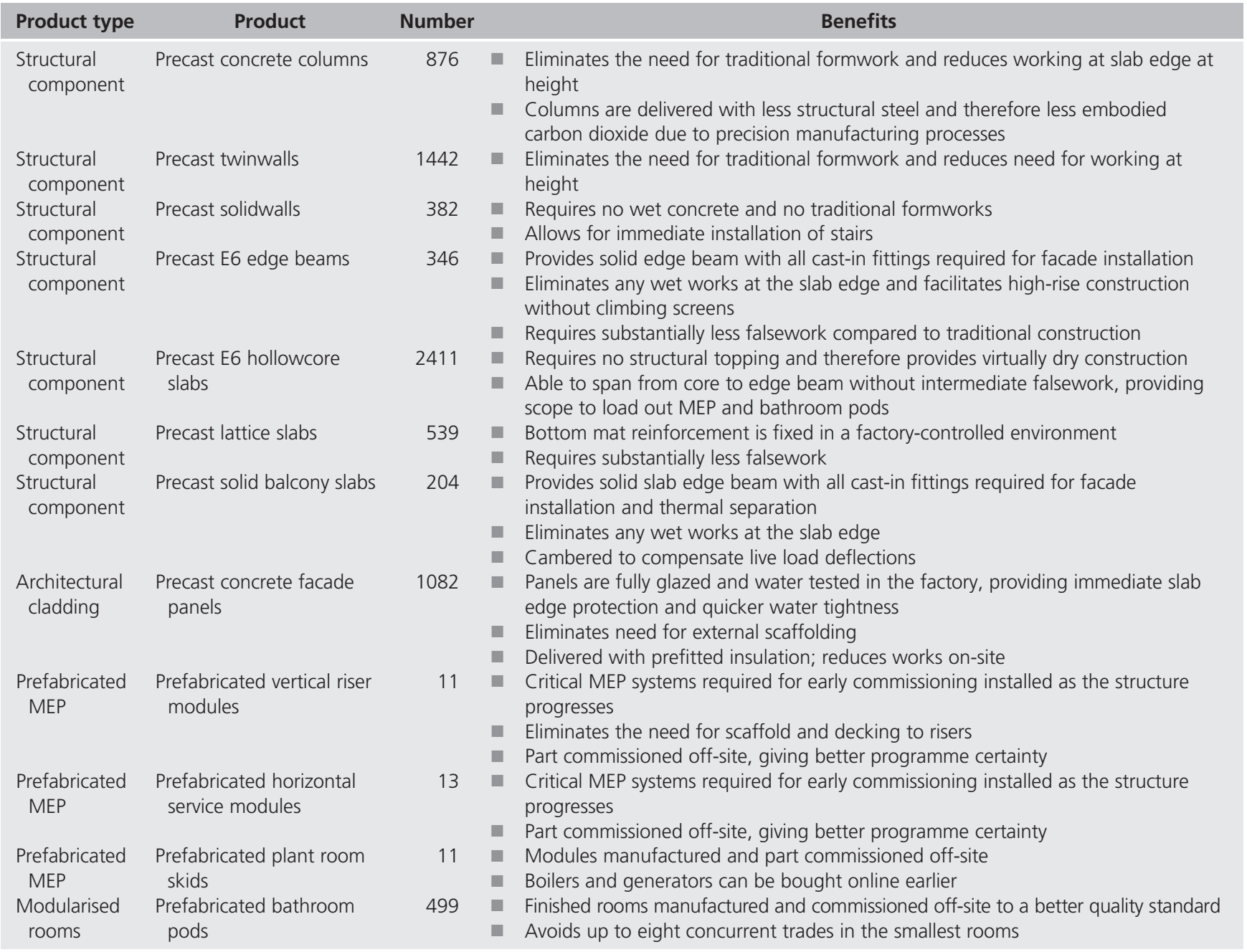


Enhancing high-rise residential

construction through design for

manufacture and assembly -

a UK case study

Banks, Kotecha, Curtis et al.

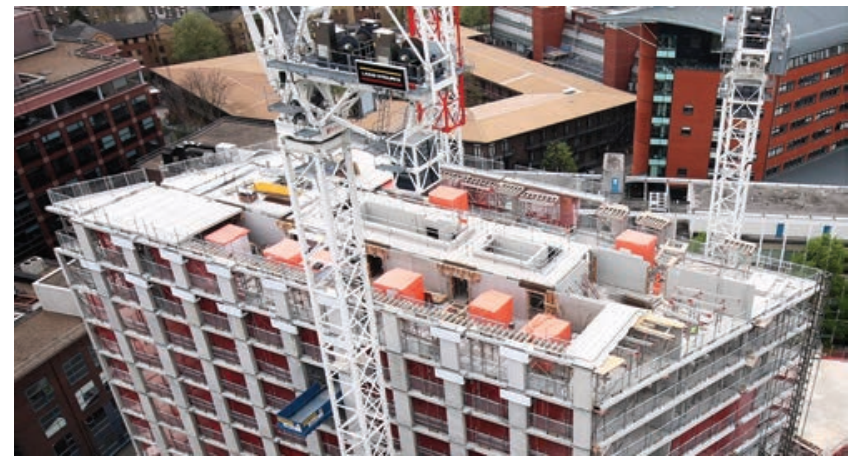

Figure 2. Aerial view of a typical floor plate under construction at Two Fifty One

facade system utilises a combination of precast concrete panels and unitised glazing. In total, the $13700 \mathrm{~m}^{2}$ facade is made up of 2300 components. As shown in Figure 3, the main elevations are clad using a single skin precast concrete panel with integrated punched windows. The benefits of this system are that the panels are air and

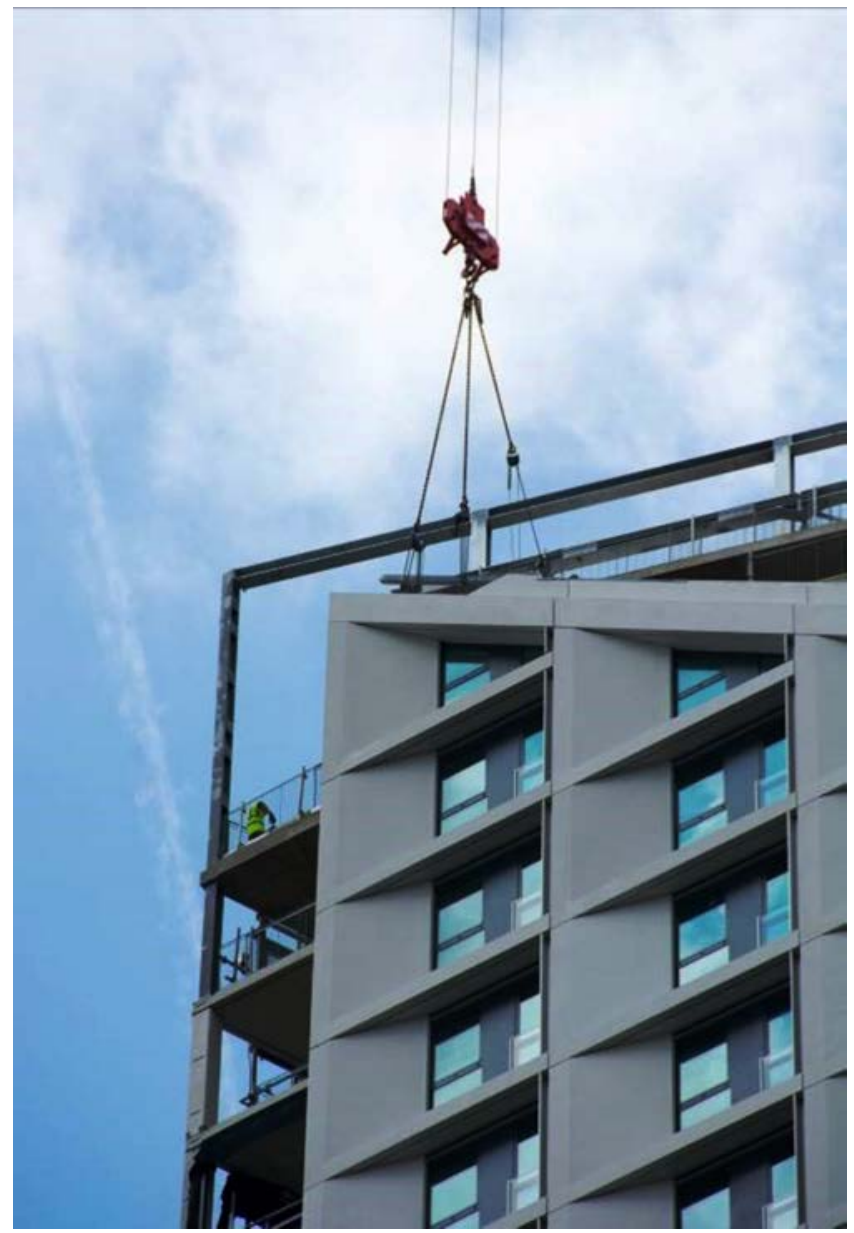

Figure 3. Precast panels with punch windows being installed at Two Fifty One water tested off-site such that the required building fabric performance is assured. The cladding follows ten floors behind the structure and is able to provide an enclosed work front prior to internal fit-out, thus making the build safer.

The modularised MEP systems are also manufactured off-site and part commissioned prior to installation. Figure 4 shows one of eleven $13 \mathrm{~m}$ long mechanical riser modules, each installed as the structure progresses. Manufacturing these off-site eliminates the need for complicated and unsafe scaffold decks and working in confined spaces. Having the MEP prefabricated means the permanent systems can be made live earlier, thus reducing the need for temporary site services. Another key success on the job has been the use of prefabricated bathroom pods. Of the 515 bathrooms required, 499 have been manufactured in a factory

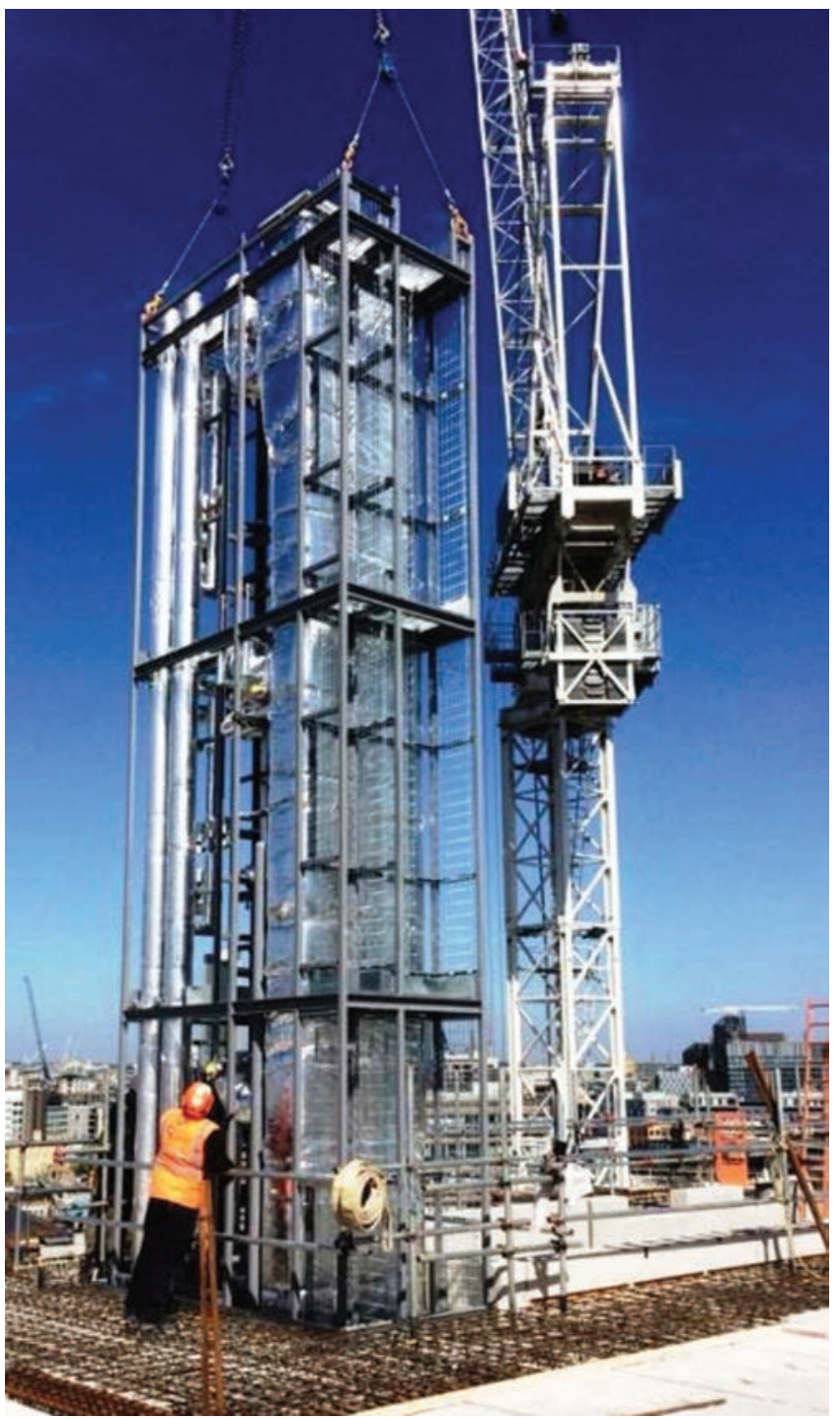

Figure 4. Prefabricated mechanical riser services four residential floors. Installed concurrently with the structure 
environment and installed concurrently with the structure, helping reduce the demands on labour and programme while helping maintain the line of balance (continuity of trades) during fit-out.

From an on-site delivery perspective, the key aspects of the system include

- the minimisation of site works which allows an extremely rapid construction process, bringing completion times forward and reduces site running costs

- the immediate development of load-bearing capacity introduces the possibility of preloading bathroom pods, prefabricated partition walls and other follow-on trades onto the floorplate to allow fit-out and handover to proceed rapidly in parallel with the frame construction

- moving works to highly controlled factory conditions ensures an extremely high level of quality control and reduces the risk of programme delays

- minimising site work greatly improves health and safety

- using standardised products facilitates the development of highly efficient designs, producing cost savings and environmental benefits

- the monolithic structure produced by the system results in a technical performance equal to conventional in situ construction.

\section{Structural design}

As mentioned earlier, successful DfMA projects require a mind-set change at the design stage. At Two Fifty One, Waterman Structures Ltd worked in collaboration with the principal contractor, the architects and the other consultants to develop the stage two design. During this time, the structural form was optimised with the product set and manufacturing capabilities in mind. For example, the team were able to reduce the thickness of the shear walls and size of the columns by the introduction of outriggers at the 20th floor. Furthermore, the introduction of the E6-H structural slab helped reduce the pile loads, and owing to the thinner construction, the gain in floor-to-floor heights compensated for the lack of tolerance, and the scheme design (Royal Institute of British Architects stage two) had been developed with.

The focus of any DfMA structural system is the connection between precast components - for example, joints between the precast units in the floor slab and the continuity steel required between wall units. Where required, joints between precast elements were designed with reduced stiffness, as the primary reinforcement is captive within the precast elements and is thus not continuous through the joints.

To accommodate office space and a desire for an exposed concrete soffit at levels one, two and three, a $275 \mathrm{~mm}$ thick composite lattice plank system was used, as shown in Figure 5. In the lattice flat slab configuration, the primary planks span between the columns and secondary planks span between shear walls and primary planks. Each plank has a $75 \mathrm{~mm}$ precast concrete biscuit with the bottom reinforcement cast in, as shown in Figure 6; the lattice girders, also shown in Figure 6, help achieve spans of up to $4.5 \mathrm{~m}$ in the temporary condition. In order to achieve continuity between the primary and secondary planks the joints are designed using reduced stiffness since the bottom layer reinforcement is not continuous through the joint and the lap bars between the planks have larger cover. Typically, primary to secondary plank joints are placed close to points of contraflexure.

A secondary benefit of the system is that the top boom of the girders used to achieve the temporary span also serves as the permanent steel in the top reinforcing layer of the secondary planks, therefore reducing the volume of on-site reinforcement fixing. Furthermore, the system has been tested and designed such that there is no bottom layer reinforcement required between secondary-to-secondary planks. The top layer reinforcement at these joints is sufficient and provides diaphragm action in the slab.

For the typical residential floors, the slab was constructed using a combination of solid planks edge beams and balcony slabs and $200 \mathrm{~mm}$ modified hollowcore planks, as shown in Figure 7. Similar to the lower floors, the E6 edge beams span between the columns and secondary hollowcore planks span between shear walls and primary planks. Both units are then stitched together using a $200 \mathrm{~mm}$ wide E6 connection.

As previously mentioned, the E6 joint is able to connect a reinforced concrete edge beam (primary span) with prestressed hollowcore planks (secondary span). As shown in the Figure 8, the primary and secondary units have cast in headed bars, which project beyond the limits of the plank, when installed the headed bars from each unit interface with one another, forming an in-plane joint through a strut and tie mechanism; see Figure 9.

Through the adoption of DfMA-led design, the sustainability credentials of the project were also enhanced through better structural design. Partial material factors reduce the assumed strength of materials in calculations and are used in structural design to account for the risk that materials are not as strong as theoretical values - for instance, poorly mixed concrete or a contaminated batch of steel - and the fact that elements are not built to the perfect accuracy assumed in design. Thus, the Eurocodes set the factors as $\gamma_{\mathrm{s}}=1 \cdot 15$ for reinforcement and $\gamma_{\mathrm{c}}=$ 1.5 for concrete for traditional construction ('a normal level of workmanship and inspection'). However, the DfMA products made at Explore Manufacturing, the principal contractor's manufacturing facility, are not traditionally constructed - the concrete is batched by a computer-controlled system and factory processes achieve better accuracy than is typically seen on-site. Therefore, it is possible to take advantage of the superior quality of the products to reduce the material factors used in their design and, hence, reduce the amount of reinforcement required.

Annex A of BS EN 1992-1-1:2004 (BSI, 2004) permits lower material factors $\left(\gamma_{\mathrm{s}}=1.05\right.$ for reinforcement and $\gamma_{\mathrm{c}}=1.35$ for concrete) if it can be shown that a higher standard of 


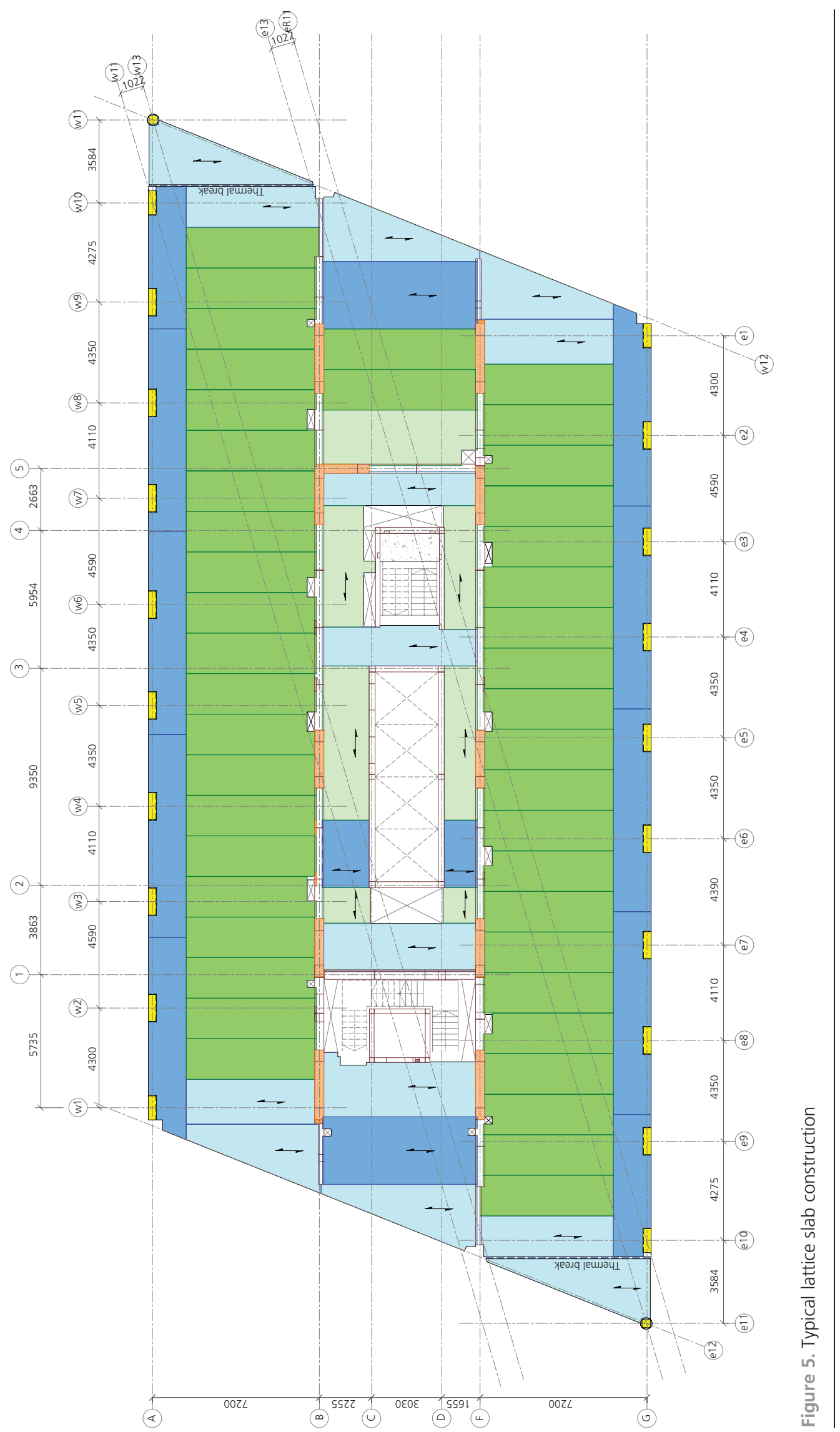


Management, Procurement and Law Volume 171 Issue MP4
Enhancing high-rise residential

construction through design for

manufacture and assembly -

a UK case study

Banks, Kotecha, Curtis et al.
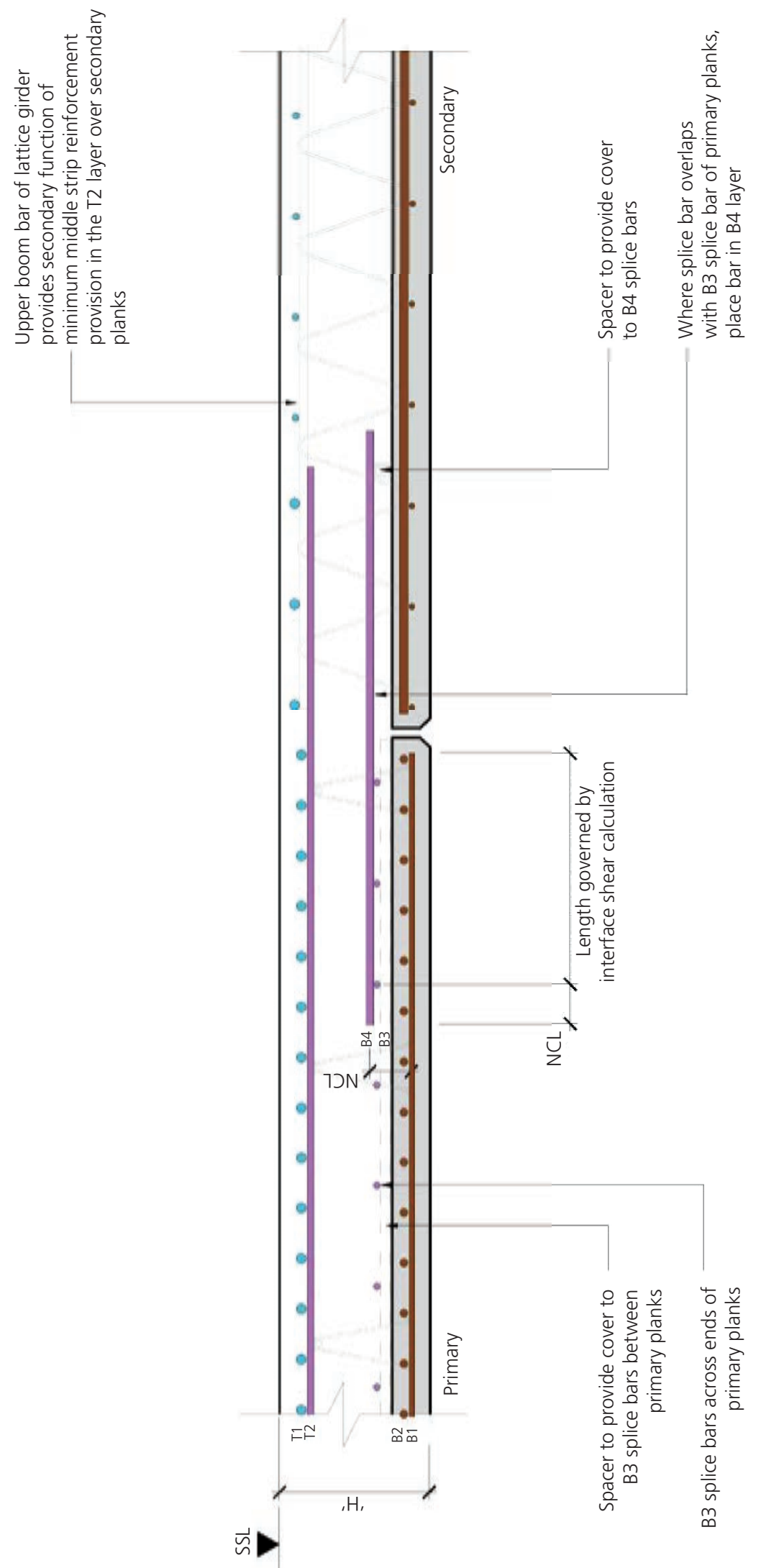


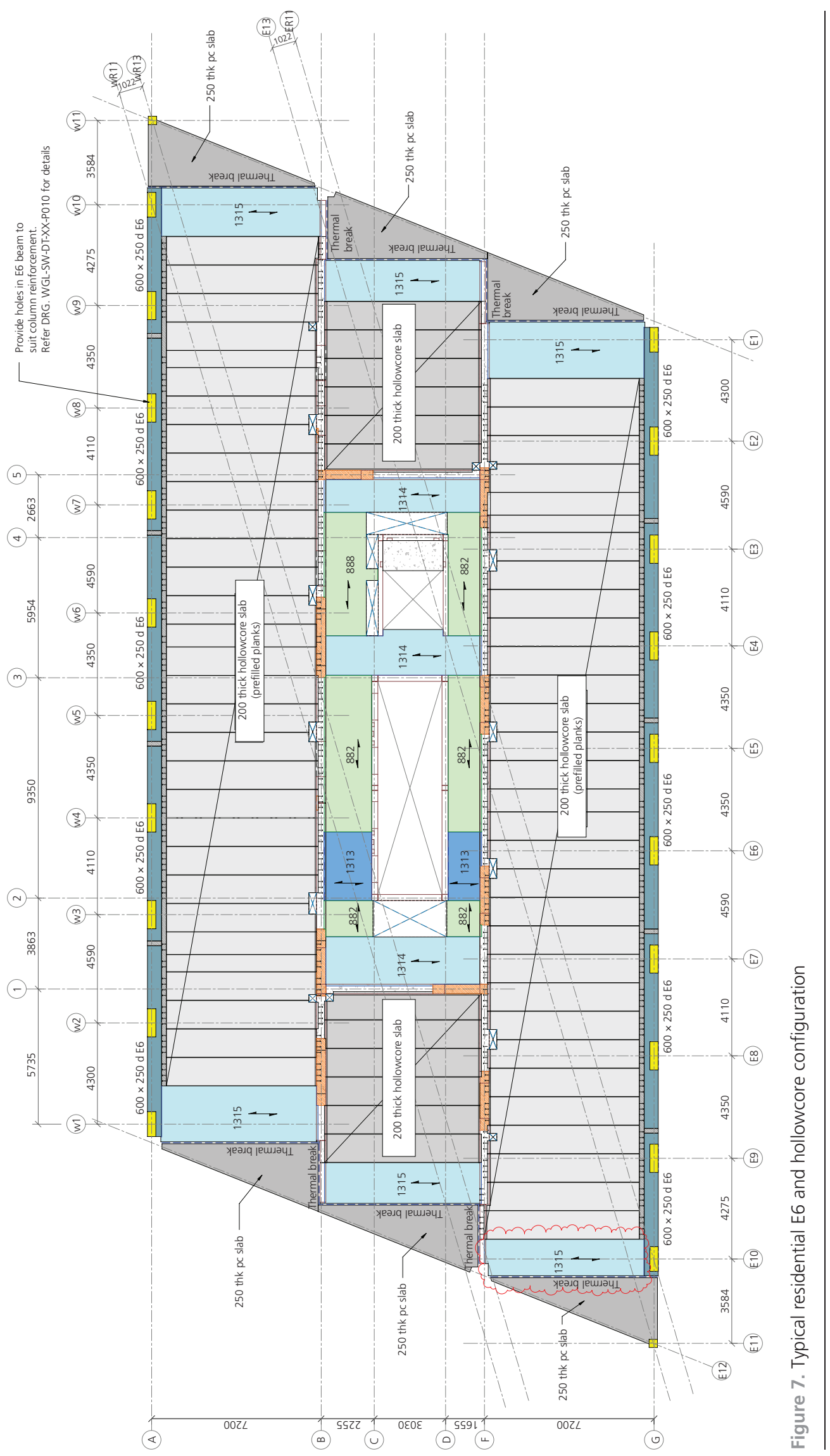




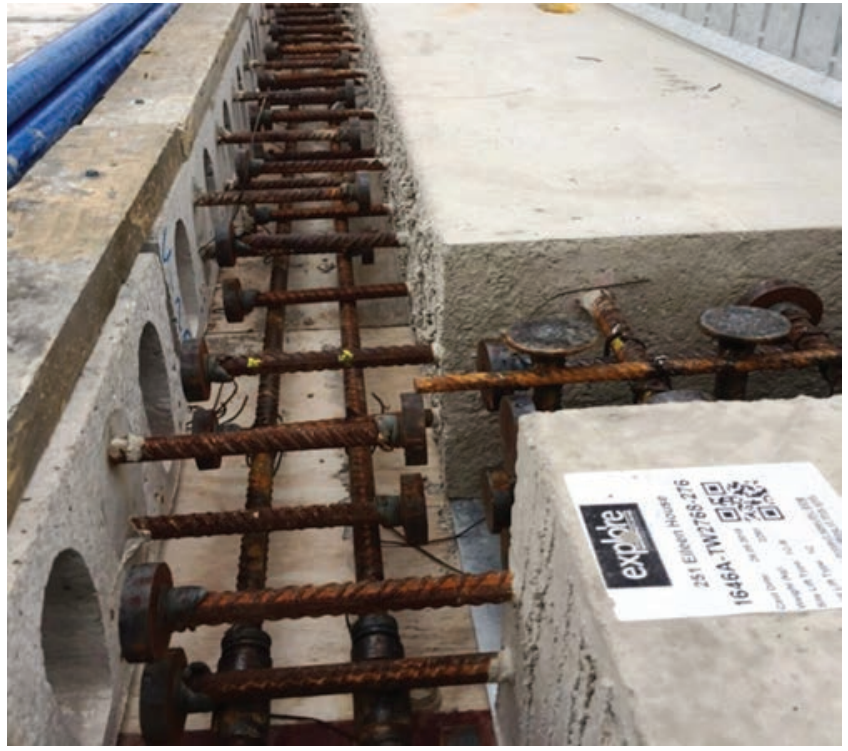

Figure 8. Interface of E6 edge beam with hollowcore secondary planks

workmanship and inspection is achieved. The Eurocode sets three conditions by which the material factors can be reduced for a precast concrete element

- The factory must meet specified quality control procedures

- The variation in concrete strength must be less than $10 \%$

- The geometric imperfections in both the overall element shape and the location of the reinforcement bars must be measured and the error included in calculations.

At Two Fifty One, all the above criteria were met, and the project team was able to reduce the percentage of the reinforcement in the columns by, on average, $25 \%$.

The successful delivery of the structural design for Two Fifty One was achieved through design coordination between the structural engineer, the architect and the component manufacturer, which reduced the construction risk and delays and allowed the smooth production of the precast elements to allow the construction programme to meet its deadlines.

\section{Manufacture}

As with any new system, the E6-H slab solution required manufacture trials to ensure that the site demands could be met and that adequate manufacturing resource could be aligned with the construction programme. Through a number of trials, the E6-H product design and manufacturing approach was fully refined to reach a position where 20 flooring products were completed in full on a daily basis. Figure 10 is indicative of a typical E6-H load ready for delivery.

The following key manufacturing challenges were successfully overcome during the E6-H product trials
- Cold weather: Maintaining the parent substrate, the hollowcore plank was kept at a minimum of $5^{\circ} \mathrm{C}$ at the time pressure pumping the cores with grout.

- Manual handling: Introduced ergonomic manual handling techniques and mechanical plant support for the installation of the headed reinforcement bars and subsequent pressure grouting.

- Resilient and flexible formwork pressure plates: A flexible and reliable formwork pressure plate was developed to accommodate manufacturing tolerances associated with the hollowcore plank, accepting a headed bar penetration at $+/-5 \mathrm{~mm}$ positional tolerance while retaining grout injected under pressure.

- Grout filling of cores: Instrumental to the viability and performance of the E6-H flooring product was the ability to fully fill intermittent cores within the hollowcore planks interrupted along their length by a centrally positioned continuous headed reinforcement bar.

\section{Product design and detailing: enhancing safety in construction}

In moving to a more componentised construction, the types of health and safety risks change when compared with traditional in situ construction. There was therefore a greater focus on lifting strategies and logistics and how these can be made safer. From the outset of the project, taking into consideration the major interface with the public domain, a backup slinging system was designed and detailed. This ensured that if any part of the primary precast product lifting system were to fail, the backup system would suspend the product, allowing it to be lowered to safety without harming the workforce or public.

In each case, the backup slinging system was designed based on the assumption that a primary lifter - that is, the lifter that would cause the most detrimental forces to the backup slinging - would fail. Based on this failure mechanism, the dynamic factor on the remaining lifters was calculated from first principles, assuming that the increase in load due to a failure could cause a $100 \mathrm{~mm}$ 'stretch' in the whole system (i.e. crane deflection and cable/chain elongation). This led the production team down the route whereby the provision of a single backup sling, direct from the hook block to an additional single cast in a lifter located directly over the centre of gravity of the unit, was made. This additional lifter takes the full load in the case of a failure of a primary lifter. Figure 11 shows a provision of a secondary backup sling secured to an E6 beam.

Further safety measures were also built into the precast columns. When a floor is constructed, the columns are the first items erected. Once installed, packers and thixotropic grout are applied to the tops of columns, preparing them to land a precast edge beam onto. For its temporary condition, the beam is then bolted to the precast column. Once the entire slab has been poured, the next set of columns are installed, which again require lose nuts and thixotropic grout to form the mechanical column to slab connection. The installation of columns therefore exposed the project to the potential risk of dropping the following off the leading edge 
Management, Procurement and Law

Volume 171 Issue MP4
Enhancing high-rise residential construction through design for manufacture and assembly -

a UK case study

Banks, Kotecha, Curtis et al.
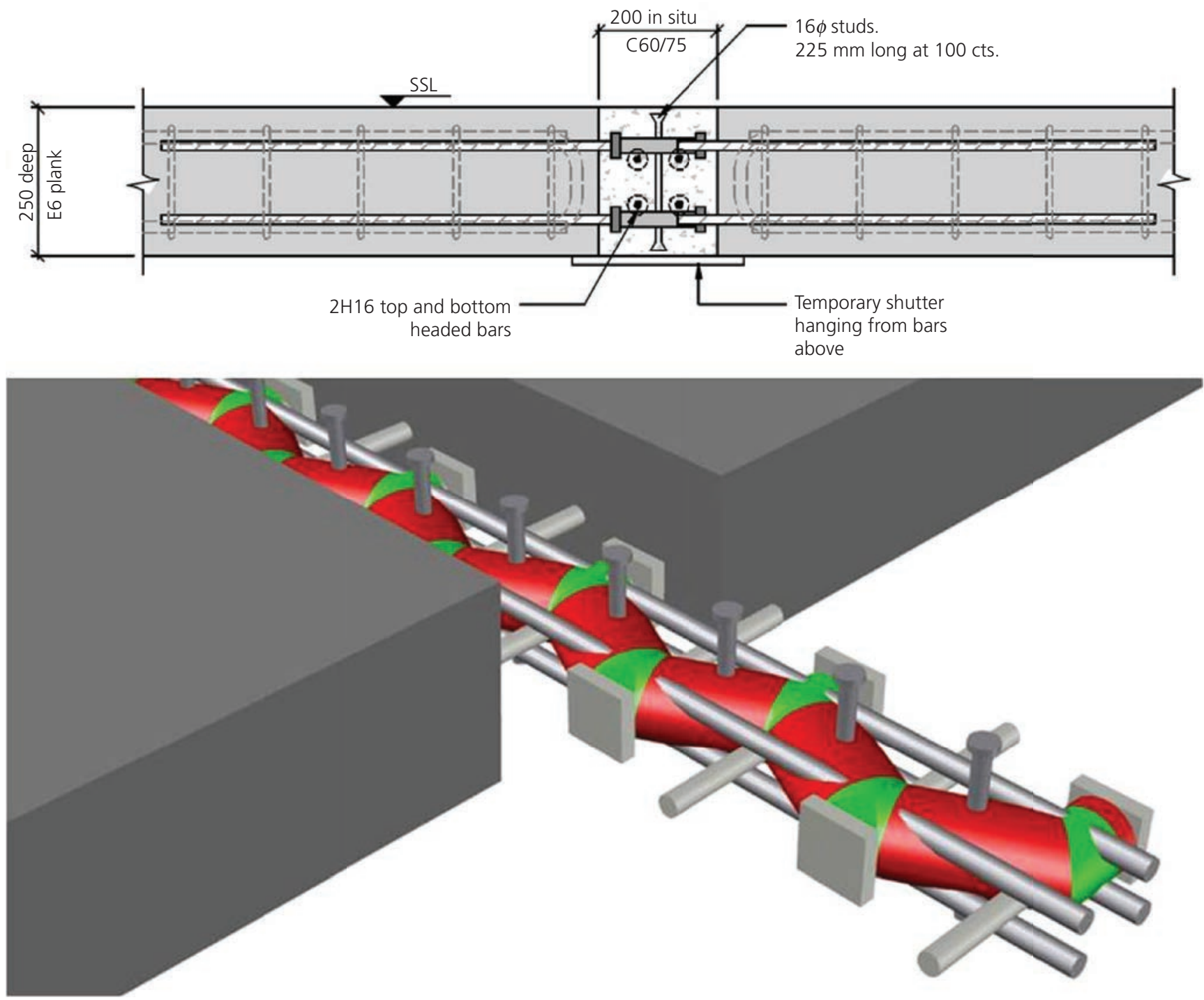

Figure 9. Typical E6 to hollowcore joint and effective strut and tie mechanism

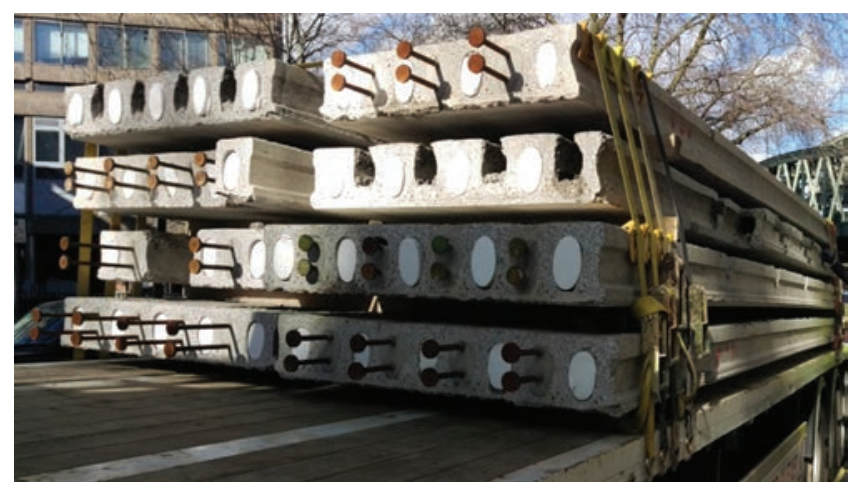

Figure 10. The E6-H floor system load ready for delivery to site

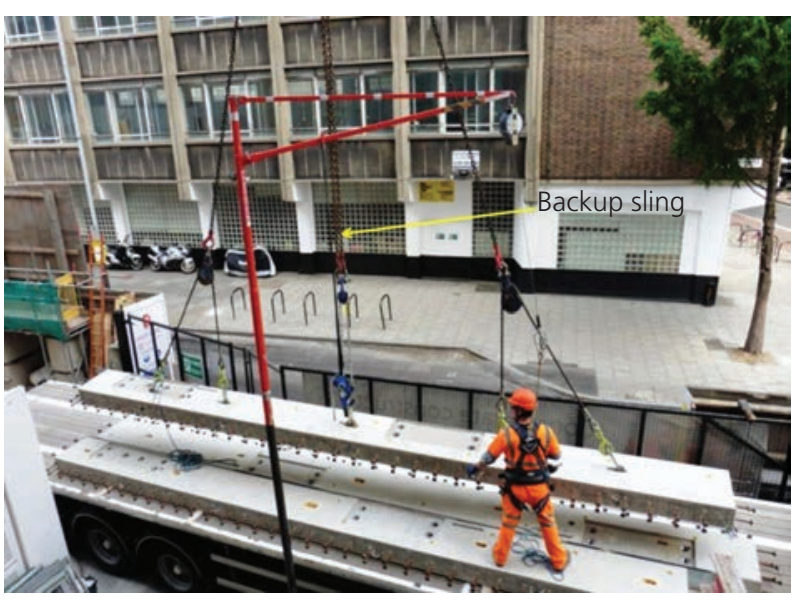

Figure 11. Use of secondary failsafe lifting 
Management, Procurement and Law

Volume 171 Issue MP4
Enhancing high-rise residential

construction through design for

manufacture and assembly -

a UK case study

Banks, Kotecha, Curtis et al. thixotropic grout

nuts

- packers

- small tools (spanners, trowels etc.).

The column hopper, shown in Figure 12, was therefore developed to ensure that at any point during construction, if any of the above were to fall, the items would be caught and unable to fall further than the column face itself.

\section{Logistics and assembly}

The Two Fifty One site was typical of many inner city island sites, occupying a parcel of land set between Newington Causeway and

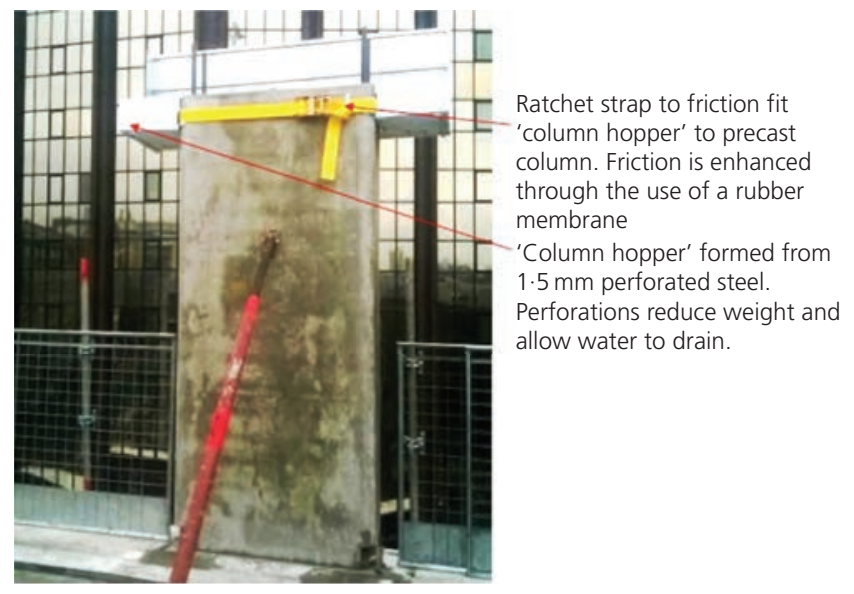

Figure 12. Precast column with column hopper in use the one-way streets of Southwark Bridge Road and Gaunt Street. As such, it required a robust logistics strategy. Figure 13 shows the site and justifies, due to limited storage space, the required 'just-in-time' philosophy with regard to delivered materials.

To deliver the project successfully, a full time DfMA coordinator was responsible for the life cycle of the components, from the factory to the point of installation. Deliveries for the project came from the West Midlands, Nottinghamshire and Derbyshire. The journey time averaged $4 \mathrm{~h}$ from factory to site. The delivery of elements was scheduled through sophisticated component-tracking technology linked with the digital model. The technology provided near real-time visibility of manufactured components enabling close monitoring by the project team.

Component delivery sequencing and load utilisation was coordinated with the haulier to ensure competent delivery and the correct sequence for off-loading on-site. A real time vehicle tracking system was adopted to monitor the progress of the delivery vehicles to ensure that the site could react to any changing traffic conditions delaying component delivery.

Three tower cranes serviced the site during the main superstructure build. Two serviced the main frame, while the third serviced cladding installation and any secondary lifting duties. Crane utilisation was the main driver in the weekly planning and precast delivery sequencing, consideration being given to the type of element, its time 'on the hook' and also its placement position on the structure and relative to other operations. The latter dictates which crane was to be used and, thus, which pit lane the load should be directed to.

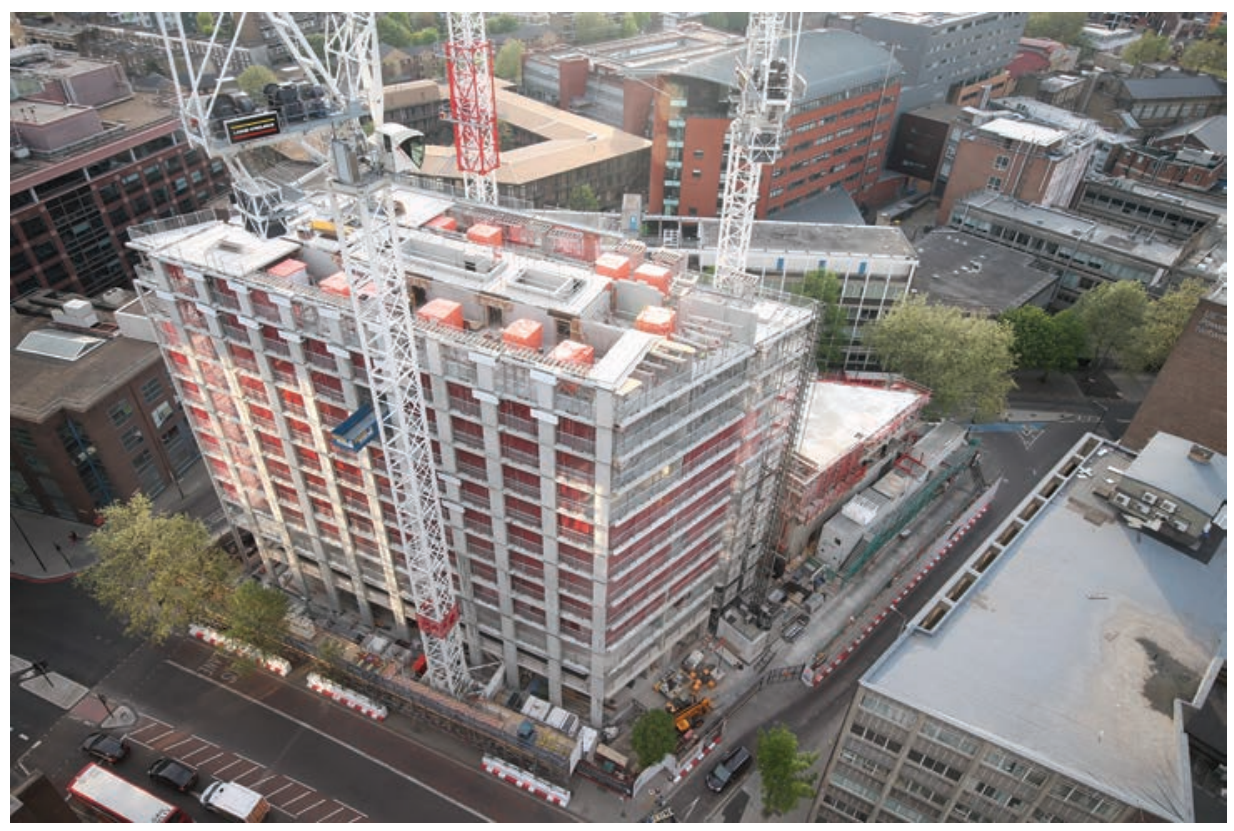

Figure 13. Two Fifty One during construction and the site constraints, including the 'pit lane' used for deliveries 
The delivery sequence was reviewed daily, to ensure that the deliveries could be fine-tuned to allow for any real-time operational constraints. Lifting procedures were developed on a product-by-product basis with the manufactures and incorporated into a component lift schedule. Due to the compact nature of the site and the difficulty in practically maintaining an exclusion zone beneath the loads being lifted, secondary lifters were installed on components, as described in Section 7.

Many of the perimeter precast components had edge protection systems installed prior to lifting into place, utilising sockets cast into the components specifically for this purpose. Larger items and hand tools followed a strict tool-tethering procedure incorporated into contract-specific high-risk work training. The intermediate floors between the working floor and the facade installation, ten floors below, utilised a post and netting system to prevent materials propagating beyond the envelope of the building.

Temporary works supports were developed ahead of the precast production, enabling propping sockets and lifting mechanisms to be fully integrated into the supplied components.

The relatively small footprint of the superstructure, together with the requirement to install bathroom pods onto the floor plant midcycle, made the sequencing and movement of any temporary support programme critical. Throughout the lifespan of the project, support schemes were reviewed further to improve efficiency and reduce the amount of materials movement between floors. Due to the interconnecting nature of the components, support was restricted to temporary plumbing of vertical elements, support to in situ concrete stitches and support to free edges of lattice planks. The layout for most of the floors remained consistent throughout the superstructure, enabling the sequencing and timings to be measured and marginal gains in each area achieved. This repetitive nature also helped clearly split operations between the installation team, with small gangs remaining responsible for the same elements of the installation on each floor. This helped improve safety, efficiency and product knowledge within the team. On average, eight deliveries of concrete components each day were received by the site. In summary, the project managed to achieve the construction of a 40-floor tower superstructure with a $6 \mathrm{~d}$ floor cycle using an installation team of just 27 operatives.

\section{Conclusion}

Two Fifty One in London has embraced the principles of DfMA, and the project team has successfully applied these to high-rise residential construction across the design disciplines. Effective off-site construction solutions have been developed and delivered for superstructure, facades, bathrooms and mechanical services at a constrained central London location. Advanced digital engineering and building information techniques have been used by the project team to facilitate the DfMA approach.

The DfMA approach has been contractor-led and has enabled the contractor to deliver the project to the client Oakmayne to very high standards. With reference back to the key advantages of DfMA, identified earlier in this case study (Section 3), the project has demonstrated tangible improvements over traditional in situ forms of construction. The construction programme has been controlled, reliable and assured. Quality standards have been consistently high. Project costs have been very well controlled in line with estimates and contract value. The safety and environmental performance of the project has been exemplary. In all respects, the project performance reinforces the stated advantages of the DfMA approach.

This project showcases an exemplar for the high-rise residential sector. It has provided key learning and improvement feedback into the maturing Laing O'Rourke DfMA operating model, reinforcing its strategy on the way that future projects should be delivered for clients.

\section{Acknowledgements}

The authors would like to thank Oakmayne Properties for its support in undertaking the project using DfMA techniques. In addition, the authors extend their thanks to the many colleagues at Laing O'Rourke, Waterman Group, Allies and Morrison and the project supply chain who have contributed to the successful construction of this project.

\section{REFERENCES}

BSI (2004) BS EN 1992-1-1:2004: Eurocode 2: Design of concrete structures. General rules and rules for buildings. BSI, London, UK. Evans J (2017) London looks to skies with record tower construction. The Financial Times, 31 March.

\section{How can you contribute?}

To discuss this paper, please email up to 500 words to the editor at journals@ice.org.uk. Your contribution will be forwarded to the author(s) for a reply and, if considered appropriate by the editorial board, it will be published as discussion in a future issue of the journal.

Proceedings journals rely entirely on contributions from the civil engineering profession (and allied disciplines). Information about how to submit your paper online is available at www.icevirtuallibrary.com/page/authors, where you will also find detailed author guidelines. 